Ritrýnd grein birt 31 desember 2021

\title{
Mat á málproska barna sem greind eru með einhverfu: Tengsl staðlaðra prófa og málsýna
}

\author{
Logi Pálsson og Jóhanna Thelma Einarsdóttir
}

Abstract

- Um höfunda

About the authors

Heimildir

\begin{abstract}
Mat á málbroska gegnir mikilvægu hlutverki í greiningu og meðferð barna með röskun á einhverfurófi. Sterk fylgni málproska snemma á lífsleiðinni er við langtímahorfur barna með einhverfu. Dar sem hluti einhverfra barna svarar stöðluðum prófum á ódæmigerðan máta gefa pau hugsanlega ekki dæmigerða mynd af málproska barnanna. Málsýni veita annað sjónarhorn á málproskamat barna sem greinast með einhverfu par sem sýni eru fengin úr sjálfsprottnu tali í náttúrulegum aðstæðum. Í pessari rannsókn var málproski 10 einhverfra barna (4;10 til 6;1 ára) athugaður með pví að leggja fyrir stöðluð málproskapróf (TOLD-2P og PPVT-4) og með pví að taka málsýni af sjálfsprottnu tali. Niðurstöður sýndu meðalsterka til mjög sterka og tölfræðilega marktæka fylgni milli málproskatölu og prófpátta TOLD-2P við mælieiningar úr sjálfsprottnu tali. Fylgni milli PPVT-4 og mælieininga úr málsýnum var meðalsterk en ekki tölfræðilega marktæk. Villugreining úr málsýnum gefur til kynna að einhverf börn geri villur af svipaðri gerð og dæmigerðir jafnaldrar en töluvert meira af peim. Í stuttu máli er með nokkrum fyrirvörum hægt að draga pá ályktun að stöðluð próf og málsýni af sjálfsprottnu tali meti sömu undirliggjandi málbættina í beygingarlega flóknu tungumáli eins og íslensku. Málfræðivillur í málsýnum, bæði eðli peirra og hlutfall, eru mikilvæg viðbót við upplýsingar sem fást með stöðluðum prófum. Frekari rannsókna á máltöku íslenskumælandi einhverfra barna er pörf.
\end{abstract}

Efnisorð: Málproski, einhverfa, stöðluð próf, málsýni

\section{Inngangur}

Mat á málproska gegnir mikilvægu hlutverki í greiningu og meðferð barna með röskun á einhverfurófi. Frávik í málproska eru gjarna hluti af einhverfu og með fyrstu einkennum sem vekja áhyggjur (Mody og Belliveau, 2013). Réttmæt mynd af málproska barnanna er mikilvæg par sem málfærni peirra á leikskólaaldri gefur sterkar vísbendingar um framtíðarhorfur (Zaidman-Zait o.fl., 2021). Einstaklingum með meiri mállega getu fyrir 6 ára aldur virðist vegna betur til lengri tíma en einstaklingum með minni mállega getu fyrir 6 ára aldur (Muller og Brady, 2016; TagerFlusberg o.fl., 2005; Tek o.fl., 2014). Við mat á málproska barna sem greind eru á einhverfurófi er vert að hafa í huga að hluti peirra svarar formlegum málproskaprófum á ódæmigerðan máta. Enn fremur er málfærni peirra mjög mismunandi en sumir mælast með málproska á pari við jafnaldra meðan aðrir eru verulega á eftir. Dessi breytileiki kemur ekki eingöngu fram í málskilningi og tjáningu heldur líka í formgerð máls hjá einhverfum og hefur haft pau áhrif að rannsakendur eru ekki á eitt sáttir um hvaða skerðingar á tali, máli og samskiptum eru lýsandi fyrir pýði einhverfra barna (Tek o.fl., 2014). 
Við mat á málproska einstaklinga með einhverfu með stöðluðum prófum hafa pættir eins og próftökuhæfni (e. test-taking skills), athygli og hvatning áhrif á niðurstöður og geta jafnvel komið í veg fyrir að réttmæt og áreiðanleg mynd af málproska pessara einstaklinga fáist. Málsýni veita annan vinkil á mat málbroska einhverfra barna par sem pau eru fengin úr sjálfsprottnu tali í náttúrulegum aðstæðum. Oftast eru bæði lögð fyrir stöðluð málproskapróf og tekin málsýni af sjálfsprottnu tali til að fá réttmæta mynd af málproska einhverfra (Condouris o.fl., 2003). Tengsl staðlaðra prófa og málsýna hafa eingöngu verið rannsökuð erlendis og hafa pær rannsóknir að mestu leyti beinst að börnum með dæmigerðan proska. Niðurstöður benda til að pessar tvær tegundir mælinga meti sömu undirliggjandi málpætti, bæði hjá börnum án proskafrávika og einhverfum enskumælandi börnum (sjá t.d. Bishop og Donlan, 2005; Ebert og Scott, 2014; Manolitsi og Botting, 2011; Norbury og Bishop, 2003; Ukrainetz og Blomquist, 2002). Markmið rannsóknarinnar var að kanna hvort málsýni af sjálfsprottnu tali meti sömu undirliggjandi málpætti og stöðluð próf í beygingarlega flóknu tungumáli eins og íslensku við mat á málproska einhverfra barna. Enn fremur var kannað hvaða upplýsingum málsýni bæta við notkun staðlaðra prófa við mat á málproska einhverfra barna.

\section{Röskun á einhverfurófi}

Greining á einhverfu er hérlendis grundvölluð á skilgreiningum röskunarinnar í handbókum Al pjóđaheilbrigðismálastofnunarinnar (e. World Health Organization) ICD-10 (e. International Statistical Classification of Diseases and Related Health Problems) (WHO, 1993) annars vegar og hins vegar í endurskoðaðri 4. útgáfu handbókar bandaríska geðlæknafélagsins DSM IV-TR (e. Diagnostic and Statistical Manual of Mental Disorders). Skilgreiningar á einhverfu eru ápekkar prátt fyrir að orðalag sé ekki nákvæmlega eins og heiti sumra flokka séu ólík. Í áranna rás hafa hugtök eins og einhverfuröskun (e. autistic disorder), einhverfa, Asperger-heilkenni, ódæmigerð einhverfa og aðrar óskilgreindar gagntækar proskaraskanir (e. pervasive developmental disorder not otherwise specified) verið sett saman í einn flokk raskana á einhverfurófi. Megnið af peim rannsóknum sem hafa verið gerðar undanfarin ár fjallar um raskanirnar á einhverfurófi í einum flokki frekar en að athuga undirflokka einhverfugreininga (Paul o.fl., 2018).

Faraldsfræðilegar rannsóknir á algengi einhverfu hérlendis benda til pess að tíðni einhverfu sé svipuð hér og fundist hefur í nýlegum rannsóknum erlendis, eða 1,2\%. Í pessum rannsóknum er byggt á greiningarviðmiðum ICD-10. Talsverður munur á algengi virðist vera milli kynja. Pannig er algengi röskunar á einhverfurófi 172,4 af hverjum 10.000 drengjum (1,72\%) en 64,8 af hverjum 10.000 stúlkum (0,65\%) (Evald Sæmundsen o.fl., 2013).

\section{Stöðluð próf og málproskamælingar einhverfra barna}

Stöðluð málproskapróf eru formlegasta og líklega algengasta aðferð við mat á málproska barna en pá er frammistaða barnsins borin saman við meðalgetu jafnaldra. Рað kann að vera vandkvæðum bundið að leggja stöðluð mælitæki fyrir börn með einhverfu og verða hér nefnd nokkur atriði. Fyrirlagnarreglur staðlaðra prófa gera ráð fyrir að barnið hafi ákveðna færni í að taka próf. Einhverf börn hafa sum hver ekki næga athygli til pess að klára fyrirlögn eða í prófaðstæðum er ekki næg hvatning til staðar til að barnið svari atriðum mælitækisins (Condouris o.fl., 2003; Tager-Flusberg, 2000). Enn fremur getur stagl einhverfra barna haft áhrif á hvernig pau svara. Stagl er sérstakt hegðunarmynstur sem lýsir sér í að börnin staglast á eða síendurtaka ákveðna hegðun (til dæmis ákveðna svörun prófatriða). Skekkja sem orsakast af stagli getur komið fram bæði á atriðum sem meta málskilning og sem meta máltjáningu (Tager-Flusberg, 2000; Waterhouse og Fein, 1982). Pá er rétt að minnast á bergmæli (e. echolalia) en mörg einhverf börn endurtaka orð og setningar og gæti pað haft áhrif á prófaniðurstöður. 
Réttmæti málproskaprófa hefur verið rannsakað með úrtökum barna með dæmigerða proskaframvindu en hörgull er á rannsóknum sem hafa athugað réttmæti mælitækjanna í öðrum úrtökum. Dó sýndi nýleg rannsókn Nordahl-Hansens og félaga (2014) sterka samsvörun milli mælitækja við athugun á málproska 55 einhverfra barna á aldrinum 2-4 ára par sem tvö stöðluð próf (Reynell Developmental Language Scale og Mullen Scales of Early Learning) voru lögð fyrir börnin ásamt að foreldrar og leikskólakennarar voru beðnir um að fylla út staðlaðan spurningalista til að meta málproskann.

Réttmætt og nákvæmt mat á málbroska einhverfra einstaklinga er mikilvægt en á sama tíma erfitt. Ekkert eitt staðlað próf dugar til pess að fá heildarmynd af málproska einhverfra barna og flest peirra hafa verulegar takmarkanir pegar pau eru notuð í pessu pýði (mismikið milli mismunandi undirhópa einhverfra einstaklinga) (Kasari o.fl., 2013). Degar verið er að meta málproska einhverfra barna er mikilvægt að hafa í huga bæði kosti og galla staðlaðra prófa. Vissulega er hagkvæmt að geta á tiltölulega skjótan máta borið einstakling saman við jafnaldra en á sama tíma er nauðsynlegt fyrir greiningaraðila að pekkja til peirra hluta sem skekkt geta niðurstöður staðlaðra prófa og takmarkað ályktunarhæfni peirra pegar kemur að einhverfum einstaklingum.

\section{Málsýni og mælingar á málproska einhverfra barna}

Málsýni af sjálfsprottnu tali geta verið réttmæt og nytsamleg viðbót við notkun staðlaðra prófa pegar mat á málproska fer fram. Málsýni geta bætt upp nokkuð af takmörkunum staðlaðra prófa. Dar má fyrst nefna gott vistfræðilegt réttmæti (e. ecological validity) par sem hægt er að taka málsýnin í náttúrulegum aðstæðum (Hewitt o.fl., 2005). Kröfur varðandi hegðun pátttakenda í matsaðstæðum eru fáar, skekkjur vegna hegðunarerfiðleika eru pví ólíklegri fyrir vikið og slíkur sveigjanleiki gerir kleift að nota málsýni hjá breiðum hópi einstaklinga með mismunandi raskanir og skerðingar (Costanza-Smith, 2010). Auk pess hefur notkun málsýna í margbreytilegum pýðishópum einstaklinga verið rannsökuð, meðal annars hjá einhverfum börnum (Manolitsi og Botting, 2011), börnum með sértæka málproskaröskun (Hewitt o.fl., 2005) tvítyngdum börnum (Restrepo, 1998) og hjá börnum með mismunandi mállýskur (Stockman, 1996). Málsýni hafa lítið verið rannsökuð hérlendis. Pó parf að nefna að Jóhanna T. Einarsdóttir og Álfhildur Dorsteinsdóttir (2015) athuguðu aldursbundin viðmið í máltjáningu íslenskra leikskólabarna út frá málsýnum af sjálfsprottnu tali. Đá hafa verið gerðar rannsóknir á máltöku íslenskra barna með skoðun málsýna (sjá t.d. Elínu Dórðardóttur, 2008; Hrafnhildi Ragnarsdóttur, 2004; Ragnheiði Dagnýju Bjarnadóttur, 2014). Engar íslenskar rannsóknir hafa verið gerðar á notkun málsýna hjá einhverfum börnum. Rannsóknargrunnurinn er pví nánast eingöngu byggður á erlendum rannsóknum og taka parf mið af pví par sem íslenska er beygingarlega flókið tungumál.

Rannsóknir á notkun málsýna við mat á málproska einhverfra barna eru tiltölulega fáar. Par að auki hafa í slíkum rannsóknum verið valdir pátttakendur með meira virkt mál en minna og litla ýgi (árásargjarna hegðun) eða sjálfsskaðandi hegðun (Tager-Flusberg, 2000). Ljóst er að slíkir pátttakendur endurspegla ekki allt pýði einhverfra einstaklinga og pess vegna litast öll umræða um rannsóknir á máli og tali í pessu pýđi af peim takmörkunum.

Rannsóknir hafa verið gerðar á tíðni samskipta hjá einhverfum börnum í mismunandi samhengi. Einhverf börn, rétt eins og mörg önnur börn með önnur frávik í málproska, virðast eiga í meiri vandræðum með samskipti (eða sýna minni tíðni samskipta) við jafnaldra heldur en fullorðna auk pess sem viðmót viðmælenda (strangt eða liðugt) hefur áhrif á samskiptatíðni (Kover o.fl., 2012; Tager-Flusberg, 2000). Rannsóknir á samskiptasamhengi hjá einhverfum börnum hafa leitt í ljós að pau, líkt og önnur börn, eru líklegust til pess að tala í pekktum aðstæðum og við pekktan viðmælanda (Kover o.fl., 2014). Í kunnuglegum aðstæðum og í viðræðum við móður kalla einhverf börn fram mál og tal sem virðist proskaðra (með tilliti til málfræðilegrar uppbyggingar) en í öðru hliðstæðu félagslegu samhengi (Tager-Flusberg, 2000). 
Bergmæli er sérkenni í máli og tali einhverfra barna sem gæti mögulega skekkt niðurstöður úr athugunum með málsýnum og á pað sérstaklega við yngri börn með einhverfu par sem notkun bergmælis minnkar með hækkandi aldri. Bergmælið getur komið til vegna setninga sem einhverf börn heyra í umhverfi sínu. Баð gæti verið eitthvað sem foreldri segir eða romsa úr sjónvarpsauglýsingu eða öðru slíku sem barnið endurtekur og hefur eftir. Баð gefur auga leið að slíkar setningar (til dæmis langar setningar úr bílaauglýsingu) endurspegla ekki raunverulegan orðaforða barnsins eða getu pess til að púsla saman löngum og flóknum setningum. Hér parf sá sem tekur málsýnið að taka ákvörðun um hvort bergmálssegðum er sleppt eða hvort pær eru teknar með í greiningu á afrituðu málsýni. Auk ofmats er líka möguleiki á vanmati í sjálfsprottnu tali einhverfra barna par sem pau eiga pað líka til að svara spurningum með eins orðs svörum (gjarnan já/nei svörum) frekar en með lengri setningum (Tager-Flusberg, 2000).

Í yfirliti sínu lýsir Tager-Flusberg (2000) rannsókn á málsýnum einhverfra barna. Í peirri rannsókn voru málsýni tekin af sjálfsprottnu tali sex ungra barna með einhverfu í samtali við móður í kunnuglegum aðstæðum. Hvert sýni var klukkustund að lengd og náðust á bilinu 300400 segðir (e. utterances) fyrir hvern einstakling. Мeð segð er átt við pað sem einstaklingur segir í einu lagi og er almenna reglan sú að ein setning er ein segð (Jóhanna Thelma Einarsdóttir og Dóra Sæunn Úlfsdóttir, 2016). Til pess að athuga (og koma í veg fyrir) áhrif bergmælis í sýnunum, voru sýnin endurafrituð pannig að 100 segðir fengust par sem allt bergmæli, frasar, eins orðs svör, ræður og söngur var tekið út úr sýnum einhverfu barnanna. Samanburður á upprunalegu afritununum og hreinsuðu afritunum leiddi í ljós að bergmálssegðir virtust ekki vera próaðri en aðrar segðir úr sýnunum með tilliti til málproska. Dvert á móti voru bergmálssegðirnar styttri og fólu í sér einfaldari setningauppbyggingu að meðaltali heldur en sjálfsprottna talið hjá börnunum Hreinsuðu sýnin, sem höfðu verið löguð pannig að möguleg skekkjuvaldandi yrt hegðun hafði verið tekin út, gáfu auðuga og nákvæma útlistun á málproska einhverfu barnanna með tilliti til máltjáningar (Tager-Flusberg, 2000).

Ljóst pykir að ákveðnir skekkjuvaldar eru til staðar pegar málsýni af sjálfsprottnu tali eru notuð til pess að meta málproska einhverfra barna. Prátt fyrir pað hafa pau verið afar nytsamleg í klínískri vinnu og rannsóknum og eru almennt talin gefa einna nákvæmasta mynd af proska máls, tals og samskipta af peim matstækjum og aðferðum sem nú eru til. Til dæmis hefur engin matsaðferð reynst jafn vel og málsýni við að útlista sérkennilega og skerta málhegðun einhverfra einstaklinga ásamt vanda peirra í félagslegum samskiptum og málnotkun (Tager-Flusberg, 2000). Đá hafa rannsakendur hvatt til notkunar málsýna við mat á málproska einhverfa barna en pau hafa talsvert verið notuð í mismunandi rannsóknum. Dar má meðal annars nefna rannsóknir sem fjalla um málproska einhverfra barna með litla mállega getu (Kasari o.fl, 2013), athuganir á mismunandi málsniðum einhverfra barna (Tek o.fl., 2014), vísvitandi samskiptafrumkvæði ómálga barna með einhverfu (Drain og Engelhardt, 2013), mat á málproska einhverfra barna á breiðu sviði mállegrar getu, með og án málhamlana (Manolitsi og Botting, 2011; Tager-Flusberg og Calkins, 1990; Volden o.fl., 2011) og tengsl staðlaðra prófa og málsýna (Condouris o.fl., 2003; Ebert og Scott, 2014).

\section{Tengsl staðlaðra prófa og málsýna}

Bæði stöðluð próf og málsýni af sjálfsprottnu tali eru notuð í klínískri vinnu. Notkun staðlaðra prófa er engu að síður algengari en notkun málsýna par sem pau eru aðgengilegri og fljótlegt er að leggja pau fyrir (Ebert og Scott, 2014). Nokkrar rannsóknir um tengsl staðlaðra málproskaprófa og málsýna meðal barna sem hafa greinst með einhverfu hafa litið dagsins ljós. Rétt er að benda á misleitni í rannsóknunum varðandi aldur pátttakenda, málfærni, val á prófum ásamt vali á mælieiningum úr málsýnum. Pá hafa niðurstöður rannsókna verið mismunandi og vel má vera að fyrrnefndri misleitni sé um að kenna.

Í rannsókn Norburys og Bishops (2003) voru pátttakendur börn á aldrinum 6-10 ára með prjár mismunandi tegundir röskunar; getumiklir einhverfir einstaklingar $(n=12)$, einstaklingar með 
málnotkunarröskun (e. pragmatic language disorder) $(n=21)$ og einstaklingar með sértæka málproskaröskun $(n=17)$. Pá voru í samanburðarhópnum 18 einstaklingar með dæmigerða framvindu proska. Engin marktæk tengsl voru á milli mælinga á stöðluðum prófum og málsýnum hjá samanburðarhópnum. Hins vegar fundust marktæk tengsl á slíkum mælingum hjá samsettum hópi tilraunahópanna priggja. Marktæk fylgni fannst milli endurtekningar setninga í stöðluðu prófi og fjölda flókinna setninga í málsýni $(r=.41)$, orðskilningi og fjölda flókinna setninga $(r$ $=.37)$ og að lokum milli orðskilnings og fjölda mikilvægra merkingarfræðilegra upplýsinga í málsýni $(r=.35)$. Dau börn í tilraunahópnum sem mældust með skertan málproska á stöðluðu prófunum, mældust líka með skertan málproska á niðurstöðum mælinga með málsýnum. Auk pess voru frávik barnanna í málbroska sýnilegri í málsýnunum heldur en í stöđluðu prófunum.

Manolitsi og Botting (2011) athuguðu hvort málsýni væru betur til pess fallin en stöðluð próf að greina á milli sérkenna í skerðingu málproska einhverfra barna og barna með sértæka málproskaröskun. Höfundar veltu fyrir sér hvort mállegar hömlur hópanna æettu sér sameiginlegar skýringar. Ein rannsóknarspurningin sneri að pví hvort málsnið fyrir hvorn hópinn fyrir sig væri svipað eða ólíkt eftir pví hvort notuð væru stöðluð próf eða málsýni. Pátttakendur voru eintyngd grískumælandi börn í tveimur hópum. Í öđrum hópnum voru 13 börn á aldrinum 4;2 til 13;0 ára með röskun á einhverfurófi og í hinum hópnum voru 13 börn á aldrinum 5;0 til 13;0 ára með sértæka málproskaröskun. Ekki kom fram marktækur munur á milli kynja eða vitsmunagreindar milli hópa. Mælingar fengnar úr málsýnum voru meðal annars uppbygging frásagnar og merkingarlegt innihald sögu og féllu pessir tveir pættir undir alhliða upplýsingar um málnotkun og mat á segðum. Auk pess var hæfni í notkun orðaforða, samtenginga, atviksorða og forsetninga athuguð. Stöðluð mælitæki voru CELF-R og CELF-P (fyrir mismunandi aldursbil). Einnig var staðlað málnotkunarpróf (The Test of Pragmatic Language - TOPL) (Phelps-Terasaki og Phelps-Gunn, 1992) lagt fyrir pátttakendur. Niðurstöður fylgnireikninga sýndu ekki marktæk tengsl milli heildartalna stöðluðu málproskaprófanna og mælinga úr málsýnum. Engu að síður kom fram sterk marktæk fylgni milli hæfni í notkun orðaforða, samtenginga, atviksorða og forsetninga í málsýnum og skilningshluta CELF (e. CELF receptive) $(r=.70)$ í hópi einhverfu barnanna. Pá kom fram örlítið veikari fylgni milli uppbyggingar frásagnar og merkingarlegs innihalds sögu í málsýnum og skilningshluta CELF $(r=.65)$ hjá einhverfu börnunum. Að lokum reiknaðist marktæk fylgni á milli hæfni í notkun orðaforða, samtenginga, atviksorða og forsetninga og TOPL $(r=.65)$ hjá börnum með einhverfu. Engin slík tengsl milli mælinga úr málsýnum og stöðluðum prófum komu fram í hópi barna með sértæka málproskaröskun (Manolitsi og Botting, 2011). Detta mismunandi mynstur tengsla milli fyrrgreindra matstækja, par sem samband milli málskilnings (úr stöðluðu prófi) og beggja tegunda mælinga úr málsýni birtist í hópi einhverfra barna, gefur til kynna að matstækin meti, í pað minnsta að einhverju leyti, sömu undirliggjandi málpætti í pessu úrtaki einhverfra einstaklinga. Skortur á slíku sambandi hjá einstaklingum með sértæka málproskaröskun getur gefið til kynna grundvallarmun á málgetu pessara tveggja greiningarhópa. Vitaskuld eru ályktunum settar skorður vegna misleits pýðis einhverfra einstaklinga en pessar niðurstöður gefa ákveðnar vísbendingar. Börn með sértæka málproskaröskun stóðu betur að vígi en einhverf börn á nokkrum mælingum úr málsýnum. Sú staðreynd rennir stoðum undir pá hugmynd að málsýni meti ekki aðeins sömu undirliggjandi málpætti og stöðluð próf, heldur geti pau í einhverjum tilfellum verið næmari en stöðluðu prófin, eins og virtist vera í pessari rannsókn. Dessar niðurstöður eru í samræmi við fyrri rannsóknir og ættu að vera hvatning fyrir talmeinafræðinga til pess að notast við málsýni samhliða stöðluðum prófum.

Að lokum rannsökuðu Condouris o.fl. (2003) sérstaklega tengsl staðlaðra prófa og málsýna af sjálfsprottnu tali. Pátttakendur voru 44 einhverf börn (7 stúlkur og 37 drengir) á aldrinum 4 til 14 ára. Pátttakendurnir voru sérvaldir á grundvelli pess að peir gæetu lokið við fyrirlögn staðlaðra prófa og pannig átti að tryggja að sem bestur samanburður fengist við mælingar úr málsýnum. Stöðluð próf sem notuð voru í pessari rannsókn voru PPVT-III, EVT og CELF. Mælingar úr málsýnum voru meðallengd segða (MLS), setningafræðistuðull (Index of Productive Syntax; IPSYN) og fjöldi mismunandi orða (FMO). Til grundvallar fylgnifylkinu (e. correlation matrix) voru settar 
niðurstöður úr mælingum úr málsýnum og niðurstöður úr báðum orðaforðaprófunum (PPVTIII og EVT) ásamt undirprófum CELF sem snertu orðasafns-, merkingar- og málfræðipekkingu, auk heildarmálbroskatölu CELF og heildarorðaforðatölu úr sameiginlegum niðurstöðum PPVTIII og EVT. Niðurstaðan var stórt fylgnifylki par sem allar fylgnitölur voru jákvæðar og flestar náðu tölfræðilegri marktekt. Marktæk fylgni reiknaðist á milli heildarmálproskatölu CELF og fjölda mismunandi orða ásamt MLS en ekki IPSYN. Einnig reiknaðist marktæk fylgni milli heildarorðaforðatölu (PPVT-III og EVT) og FMO. Enn fremur kom fram marktæk fylgni milli FMO og undirprófs CELF sem metur orðasafns- og merkingarfræðigetu. Pá birtist marktæk fylgni milli MLS og bæði undirprófs CELF sem metur orðasafns- og merkingarfræðigetu og undirprófs CELF sem metur málfræði. Ekki kom fram marktæk fylgni milli IPSYN og annarra mælinga úr stöðluðum prófum. Dessar niðurstöður renna stoðum undir pá hugmynd að stöðluð próf og málsýni meti sama undirliggjandi málpáttinn í pýði einhverfra einstaklinga.

Óhætt er að segja að ákveðinn breytileika sé að finna í rannsóknum sem hafa kannað tengsl staðlaðra prófa og málsýna. Prátt fyrir pennan breytileika virðast niðurstöður vera í pá átt að málsýni og stöðluð próf meti sömu undirliggjandi málpætti, að minnsta kosti á peim páttum sem hafa verið athugaðir í rannsóknum. Nauðsynlegt er að hafa í huga að pátttakendur eru oft fáir í rannsóknunum og á breiðu aldursbili sem getur virkað takmarkandi, sérstaklega par sem pátttakendur sýna mjög misjafna færni í tungumálinu. Að lokum er nauðsynlegt að nefna að allar rannsóknir par sem skoðuð hafa verið tengsl staðlaðra prófa og málsýna hafa farið fram í öðru málumhverfi en íslensku. Íslenska er, sem fyrr segir, sérstök hvað varðar beygingar og fjölbreytileika málfræðiatriða. Nauðsynlegt er að athuga hvort tengsl staðlaðra prófa og málsýna, sem fundist hafa í erlendum tungumálum, finnist í beygingarlega flóknu tungumáli eins og íslensku.

\section{Markmið og rannsóknarspurningar}

Tvær rannsóknarspurningar voru settar fram um niðurstöður rannsóknarinnar:

1. Meta stöðluð málproskapróf og málsýni af sjálfsprottnu tali sömu undirliggjandi pætti hjá einhverfum einstaklingum er varðar orðaforða, setningafræði og málfræði í beygingarlega flóknu tungumáli eins og íslensku?

2. Geta málsýni bætt upplýsingum við notkun staðlaðra málproskaprófa pegar meta á málproska einstaklinga með einhverfu?

\section{Aðferð}

\section{Pátttakendur}

Pátttakendur rannsóknarinnar voru 10 börn (9 drengir og 1 stúlka) á aldrinum 4;10 til 6;1 ára og voru valdir af hentugleika frá hausti 2016 fram á vor 2017 (sjá Töflu 1). Aðgangur að pátttakendum var fenginn í gegnum stofur sjálfstætt starfandi talmeinafræðinga sem skrifað höfðu undir yfirlýsingu um vilja til samstarfs við rannsakendur. Talmeinafræðingarnir höfðu samband við foreldra/forráðamenn gjaldgengra pátttakenda, sýndu peim og afhentu upplýsingablað og sampykkisblað fyrir pátttöku. Leitað var eftir börnum af báðum kynjum á höfuðborgarsvæðinu með ákveðna læknisfræðilega greiningu.

Pátttökuviðmið voru eftirfarandi: Börnin purftu að vera á aldrinum 4 til 7 ára, með greiningu um röskun á einhverfurófi (ICD-10: bernskueinhverfa, F84.0; ódæmigerð einhverfa, F84.1; Asperger-heilkenni, F84.5; aðrar gagntækar proskaraskanir, F84.8; gagntæk proskaröskun, ótilgreind, F84.9 t.d.). Einhverf börn án máltjáningar voru útilokuð frá pátttöku af augljósum ástæðum. Tví- eða fjöltyngi og stam útilokaði ekki einstaklinga frá pátttöku og voru peir pættir ekki kannaðir. 
Tafla 1. Aldur og kyn pátttakenda.

\begin{tabular}{lll}
\hline Númer & Aldur & Kyn \\
\hline 1 & $5 ; 8 ; 17$ & $\mathrm{kk}$ \\
2 & $6 ; 1 ; 2$ & $\mathrm{kk}$ \\
3 & $5 ; 3 ; 16$ & $\mathrm{kk}$ \\
4 & $5 ; 0 ; 8$ & $\mathrm{kk}$ \\
5 & $4 ; 10 ; 9$ & $\mathrm{kk}$ \\
6 & $5 ; 2 ; 0$ & $\mathrm{kvk}$ \\
7 & $4 ; 11 ; 24$ & $\mathrm{kk}$ \\
8 & $5 ; 9 ; 15$ & $\mathrm{kk}$ \\
9 & $6 ; 1 ; 5$ & $\mathrm{kk}$ \\
10 & $5 ; 1 ; 25$ & $\mathrm{kk}$ \\
\hline
\end{tabular}

\section{Mælitæki}

Tvö stöðluð próf voru lögð fyrir hvern pátttakanda, annars vegar staðlað málproskapróf (TOLD2P) (Ingibjörg Símonardóttir o.fl., 1995) og hins vegar orðaforðapróf (PPVT-4) (Dunn og Dunn, 2007). Auk stöðluðu prófanna var málsýni af sjálfsprottnu tali í leik tekið af hverjum pátttakanda.

TOLD-2P er staðlað málproskapróf fyrir börn á aldrinum 4;0 til 8;11 ára. Prófið var upphaflega samið og staðlaðíBandaríkjunum. Íslensk pýðing og staðfærsla var gerð árið 1995. Prófið inniheldur sjö undirpróf til pess fallin að greina málproskafrávik hjá börnum: (1) Myndir - orðpekking, (2) Ordskilningur, (3) Túlkun setninga, (4) Endurtekning setninga, (5) Botnun setninga, (6) Hljódgreining og (7) Framburður. PPVT-4 er staðlað bandarískt skilningsorðaforðapróf sem er ætlað einstaklingum frá tveggja ára aldri og hefur ekki verið staðfært að íslensku pýði. Við töku og afritun málsýna var stuðst við leiðbeiningar úr Handbók um málsýni (Jóhanna Thelma Einarsdóttir og Póra Sæunn Úlfsdóttir, 2016). Deir mælikvarðar sem voru notaðir til að leggja mat á málproska með málsýnum voru meðallengd segða (MLS), heildarfjöldi orða (HFO), fjöldi mismunandi orða (FMO) og hlutfall málfreððivillna.

\section{Framkvæmd rannsóknar, öflun gagna og úrvinnsla}

Prófanir fóru annars vegar fram á stofu sjálfstætt starfandi talmeinafræðinga og hins vegar í skólum viðkomandi pátttakenda. Foreldrum var boðið að koma með barnið á stofu til prófunar eða að prófandi myndi heimsækja barnið í skólann og prófa á skólatíma ef pað hentaði betur. TOLD-2P var alltaf lagt fyrir fyrst, síðan PPVT-4 og að lokum var tekið málsýni af sjálfsprottnu tali í frjálsum leik og afritaðar 50 fyrstu segðir barnsins. Í öllum tilfellum tókst að ljúka fyrirlögn og sýnatöku í einni lotu. Prófun tók á bilinu 60 til 90 mínútur. Tveir pátttakendur voru prófaðir á stofu sjálfstætt starfandi talmeinafræðings en átta í skólum.

Snjallsími (Samsung Galaxy Note 3) var notaður til að taka upp málsýni hjá öllum pátttakendum. Bæði var um hljóð- og myndbandsupptöku að ræða. Málsýnin voru afrituð í ritvinnsluforrit og gengið var úr skugga um að hvorki bergmálstal né stagl væri afritað og myndi skekkja niðurstöður. Ekki purfti að útiloka neinar segðir vegna pessa. Að lokinni afritun málsýna var sýnunum hlaðið niður í forritið Málgreinir (Jóhanna Thelma Einarsdóttir og Stefán Carl Peiser, 2016). Forritið gerir orðtíðnitalningu ásamt að telja og reikna heildarfjölda segða (HS), meðallengd segða (MLS), heildarfjölda orða (HFO), fjölda mismunandi orða (FMO), fjölda óskiljanlegra orða, fjölda já/nei svara og hlutfall málfræðivillna í málsýni sem pað er matað á. Deir mælikvarðar úr málsýnunum 
sem átti að vinna með voru valdir úr útreikningum forritsins og teknir með til tölfræðilegrar úrvinnslu. Forritið er hægt að nálgast í opnum aðgangi á netinu.

Forritin Microsoft Excel 2016 og IBM SPSS Statistics (SPSS) voru notuð í alla tölfræðilega úrvinnslu.

Athugun á áreiðanleika fyrir afritun málsýna var gerð. Tvö sýni (20\%) voru valin af handahófi. Tveir meistaranemar í talmeinafræði (Á1 og Á2) voru fengnir til bess að afrita bæði sýnin sitt 1 hvoru lagi. Afritanir peirra voru svo bornar saman við afritun höfundar. Áreiðanleiki var reiknaður fyrir mælieiningarnar MLS, HFO og FMO. Reyndist samræmi milli matsmanna vera fyrir fyrra sýnið 95,1\% til 100\% og fyrir seinna sýnið 83,6 \% til 93,5\%. Detta samræmi milli matsmanna á afritun málsýna og er svipað pví sem aðrar birtar rannsóknir hafa gefið upp um áreiðanleika afritunar (Finestack o.fl., 2014; Manning o.fl., 2020).

\section{Niðurstöður}

Í Töflu 2 má sjá niðurstöður mælinga á málproskaprófinu TOLD-2P og orðaforðaprófinu PPVT4.

Tafla 2. Niðurstöður staðlaðra málproskaprófa TOLD-2P (málproskatala og niðurstöður prófpátta) og PPVT-4 (orðskilningur).

\begin{tabular}{cccccccc}
\hline Pátttakandi & $\begin{array}{c}\text { Málproska- } \\
\text { tala }\end{array}$ & Hlustun & Tal & $\begin{array}{c}\text { Merkingar- } \\
\text { fræði }\end{array}$ & $\begin{array}{c}\text { Setninga- } \\
\text { fræði }\end{array}$ & $\begin{array}{c}\text { Hljóðkerfis- } \\
\text { fræði }\end{array}$ & $\begin{array}{c}\text { PPVT-4 (orð- } \\
\text { skilningur) }\end{array}$ \\
\hline 1 & 43 & 59 & 44 & 80 & 46 & 46 & 50 \\
2 & 88 & 83 & 94 & 93 & 88 & 91 & 108 \\
3 & 59 & 67 & 64 & 87 & 64 & 58 & 75 \\
4 & 53 & 56 & 64 & 83 & 51 & 69 & 66 \\
5 & 87 & 109 & 73 & 103 & 75 & 97 & 79 \\
6 & 48 & 56 & 64 & 77 & 68 & 46 & 94 \\
7 & 71 & 72 & 75 & 90 & 75 & 65 & 83 \\
8 & 71 & 88 & 64 & 109 & 62 & 65 & 85 \\
9 & 72 & 75 & 75 & 87 & 68 & 84 & 85 \\
10 & 83 & 90 & 81 & 83 & 75 & 110 & 88 \\
\hline
\end{tabular}

Meðaltal prófpátta og málproskatölu í íslenskri stöðlun og staðfærslu TOLD-2P er 100 og staðalfrávik 15. Niðurstöður hjá pátttakendum 2 og 5 eru innan meðalmarka (við neðri mörk meðalmarka sem liggja einu staðalfráviki neðan og ofan meðaltals, 85-115). Málproski allra hinna pátttakendanna er meira en einu staðalfráviki neðan meðalmarka. Meðaltal PPVT-4 er 100 og staðalfrávik 15. Pátttakendur 2, 5, 6, 8, 9 og 10 sýna frammistöðu sem fellur innan eins staðalfráviks ofan og neðan meðaltals (85-115). Pátttakendur 1, 3, 4, 5 og 7 sýna frammistöðu neðan meðalmarka ef miðað er við eitt staðalfrávik frá meðaltali. 
Tafla 3. Niðurstöður úr mælingum málsýna.

\begin{tabular}{ccccc}
\hline Pátttakandi & MLS & HFO & FMO & Villuhlutfall \\
1 & 1,74 & 87 & 48 & $4,5 \%$ \\
2 & 3,88 & 198 & 105 & $4,0 \%$ \\
3 & 2,31 & 120 & 56 & $2,5 \%$ \\
4 & 2,28 & 114 & 72 & $4,4 \%$ \\
5 & 4,35 & 222 & 94 & $7,7 \%$ \\
6 & 2,38 & 119 & 46 & $3,4 \%$ \\
7 & 2,89 & 162 & 88 & $7,4 \%$ \\
8 & 3,92 & 196 & 95 & $5,1 \%$ \\
9 & 3,61 & 195 & 81 & $8,7 \%$ \\
10 & 3,75 & 195 & 108 & $6,7 \%$ \\
\hline
\end{tabular}

Lýsandi tölfræði fyrir mælieiningar úr málsýnum af sjálfsprottnu tali má sjá í Töflu 3. Ef meðalgeta pátttakenda er borin saman við viðmið fyrir íslensk börn má sjá að pátttakendur rannsóknarinnar (4;10-6;2 ára) eru með MLS á svipuðu róli og 3;0-3;5 ára, HFO svipað og 3,5-4;0 ára og FMO eins og 3;0-4;0 ára gömul börn með dæmigerðan proska. Villuhlutfallið liggur á bilinu 2,5\% upp 1 8,72\%. Íslensk viðmið fyrir hlutfallslegan fjölda villna hjá börnum liggur frá 2,0\% hjá 4;6 ára og lækkar niður í 1,6\% hjá 6;0 ára gömlum börnum.

\section{Tengsl staðlaðra prófa og málsýna}

Fylgni (e. bivariate Pearson's correlation) var reiknuð fyrir mælitölur allra prófpátta TOLD-2P ásamt málproskatölu, mælitölu PPVT-4 auk mælinga úr málsýnum af sjálfsprottnu tali (MLS, HFO og FMO). Niðurstöður fylgnireikninga má sjá í Töflu 4. Í fylgnifylkinu eru fylgnistuðlar sem ná tölfræðilegri marktekt miðað við $p<0,01$ merktir með * og peir stuðlar sem ná tölfræðilegri marktekt miðað við $p<0,001$ merktir með $\star \star$.

Tafla 4. Fylgnistuðlar milli prófpátta staðlaðra matstækja og mælieininga úr málsýnum.

\begin{tabular}{ccccccccccc}
\hline & & 1 & 2 & 3 & 4 & 5 & 6 & 7 & 8 & 9 \\
\hline 1 & Málproskatala & & & & & & & & & \\
2 & Hlustun & $.88^{* *}$ & & & & & & & & \\
3 & Tal & $.85^{* *}$ & .52 & & & & & & & \\
4 & Merkingarfræði & .60 & $.75^{*}$ & .25 & & & & & & \\
5 & Setningafræði & $.83^{* *}$ & .59 & $.92^{* *}$ & .30 & & & & & \\
6 & Hljóðkerfisfræði & $.88^{* *}$ & $.77^{* *}$ & $.76^{*}$ & .31 & .63 & & & & \\
7 & PPVT-4 & .63 & .36 & $.85^{* *}$ & .24 & $.88^{* *}$ & .44 & & & \\
8 & MLS & $.93^{* *}$ & $.92^{* *}$ & $.71^{*}$ & $.73^{*}$ & $.70^{*}$ & $.80^{* *}$ & .62 & & \\
9 & HFO & $.94^{* *}$ & $.90^{* *}$ & $.74^{*}$ & $.70^{*}$ & $.73^{*}$ & $.81^{* *}$ & .62 & $.99^{* *}$ & \\
10 & FMO & $.92^{* *}$ & $.78^{* *}$ & $.78^{* *}$ & .59 & $.67^{*}$ & $.86^{* *}$ & .54 & $.87^{* *}$ & $.88^{* *}$ \\
\hline$\star_{\mathrm{p}}<0,01, \star \star \mathrm{p}<0,001$ & & & & & & & & & &
\end{tabular}


Allir fylgnistuðlar fylgnifylkisins voru jákvæðir og meirihluti peirra, eða 30 af 45, náði tölfræðilegri marktekt ( 9 miðað við $p<0,01$ og 21 miðað við $p<0,001$ ). Fylgni milli mælinga úr málsýnum af sjálfsprottnu tali var mjög sterk og marktæk miðað við $p<0,001$, á bilinu .87.99. Fylgnistuðull milli málproskatölu og PPVT-4 var jákvæður og meðalsterkur (.63) en náði ekki tölfræðilegri marktekt. Einu fylgnistuðlarnir í fylgnifylkinu sem PPVT-4 fékk tölfræðilega marktekt fyrir voru við prófpættina tal (.85) og setningafreði (.88) miðað við $p<0,001$. Fylgni milli málproskatölu TOLD-2P og mælinga úr málsýnum var mjög sterk (.92-.94) og marktæk miðað við $p<0,001$. Tölfræðilega marktækir fylgnistuðlar mælinga úr málsýnum og prófpátta TOLD-2P voru á bilinu .67 (meðalsterk fylgni) til .92 (mjög sterk fylgni) og aðeins einn stuðull (milli FMO og prófpáttarins merkingarfræði) náði ekki tölfræðilegri marktekt.

\section{Tegundir málfræðivillna í málsýnum}

Tegundir villna í málsýnum voru greindar sérstaklega á eftirfarandi hátt: Villur hvers málsýnis fyrir sig voru skráðar sérstaklega. Segðin sem villan kom fyrir í var líka skráð til pess að gefa skýra mynd af eðli villunnar. Deir orðflokkar sem villur komu fyrir í voru skráðir og talið hve margar villur voru í hverjum orðflokki. Brottfall orða úr setningum var einnig skráð og talið sem og röng orðaröð. Niðurstöður má sjá í Töflu 5.

Tafla 5. Villugreining úr málsýnum.

\begin{tabular}{ccc}
\hline Villuflokkar & Fjöldi villna & Hlutfall \\
\hline Sagnorð & 28 & $30 \%$ \\
Fornöfn & 17 & $18,5 \%$ \\
Nafnorð & 17 & $18,5 \%$ \\
Lýsingarorð & 14 & $15 \%$ \\
Brottfall & 8 & $9 \%$ \\
Atviksorð & 3 & $3 \%$ \\
Töluorð & 2 & $2 \%$ \\
Orðaröð & 2 & $2 \%$ \\
Forsetning & 1 & $1 \%$ \\
Alls & 92 &
\end{tabular}

Við flokkun villna kom í ljós að flestar villur komu fram í sagnbeygingu eða 30\% allra villna í málsýnum. Par á eftir komu fornöfn og nafnorð með sama hlutfallið. Dá sneru 15\% villna að notkun lýsingarorða. Brottfall átti sér stað á átta stöðum eða í 9\% tilvika. Villur sem sneru að atviks- og töluorðum voru einungis fimm í heildina og röng orðaröð var tvisvar. Ein villa birtist í notkun forsetningar. Í heildina komu fram 92 villur í málsýnunum. Ein tegund alhæfingar fannst hjá tveimur pátttakendum par sem endingin -ið var sett á eftir sögn sem kom á eftir hjálparsögninni „,að geta“ í framsöguhætti (Ég get ekki „gerið“ við hana; Hann getur „,hoppið“ hann Angrybirds). Geta er oftast hjálparsögn og tekur með sér lýsingarhátt pátíðar (ég get komið). Dessi regla virðist vera alhæfð fyrir lýsingarhátt pátíðar hjá pátttakanda 2 og 5.

\section{Umræða}

Niðurstöðurnar benda til pess að stöðluð málproskapróf og mælingar úr málsýnum af sjálfsprottnu tali meti að miklu leyti sömu málpættina fyrir einhverf börn er varðar orðaforða, setningafræði 
og málfræði í beygingarlega flóknu tungumáli eins og íslensku. Niðurstöður eru að miklu leyti í samræmi við erlendar rannsóknir sem hafa verið gerðar á pessu efni (sjá til dæmis Condouris o.fl., 2003). Greiningar á málsýnum af sjálfsprottnu tali benda til pess að pau geti bætt upplýsingum við notkun staðlaðra málproskaprófa pegar meta á málproska einhverfra barna sem tala íslensku. Viðbótarupplýsingar sem málsýni veita eru hlutfall málfræðivillna og flokkun peirra. Í ljós kom að hlutfall málfræðivillna í málsýnum einhverfu barnanna í úrtakinu er hærra en barna með dæmigerða proskaframvindu. Slíkra niðurstaðna mátti ef til vill vænta ef litið er til frammistöðu pátttakendanna á TOLD-2P og PPVT-4 ásamt niðurstöðum annarra mælieininga úr málsýnum. Gróf flokkun sýndi að villur sem komu fram í málsýnum einhverfu barnanna í úrtakinu eru ápekkar peim sem börn með dæmigerðan proska sýna, en pó að villurnar væru svipaðar var meira af peim. Auk pess má koma auga á fyrirbæri eins og alhæfingu málfræðireglna pegar villur í sjálfsprottnu tali eru skoðaðar sérstaklega í málsýnum.

\section{Fylgni}

Tengsl staðlaðra prófa og málsýna af sjálfsprottnu tali voru skoðuð með fylgnireikningum. Í stuttu máli fundust almennt sterk tengsl milli prófpátta staðlaðra prófa og mælieininga úr málsýnum. Í ljós kom að mjög sterk jákvæð og tölfræðilega marktæk fylgni reiknađist milli allra mælieininga úr málsýnum (MLS, HFO og FMO) og málproskatölu TOLD-2P. Pað má túlka á pann hátt að mælieiningar málsýna séu góður mælikvarði á málproska einhverfu barnanna í pessari rannsókn. Með öðrum orðum má segja að samtímaréttmæti (e. concurrent validity) milli TOLD-2P og mælieininga úr málsýnum sé gott. MLS og HFO sýndu sterka marktæka jákvæða fylgni við alla prófpætti TOLD-2P og pví má segja að pessar tvær mælieiningar meti að miklu leyti sömu málpætti og undirprófin hlustun, tal, merkingarfraði, setningafraði og hljóðkerfisfraði en pessir pættir byggja upp málproskatölu TOLD-2P. FMO sýndi meðalsterka til sterka fylgni við alla prófpættina en tölfræðileg marktekt fékkst ekki fyrir stuðul FMO og merkingarfreði. Dessar upplýsingar gefa góðar vísbendingar um að stöðluð málproskapróf og málsýni meti sömu undirliggjandi pætti hjá einhverfum börnum er varðar orðaforða, setningafræði og málfræði í beygingarlega flóknu tungumáli eins og íslensku.

Fylgnistuðlar orðaforðaprófsins PPVT-4 og málsýnanna fengu ekki tölfræðilega marktekt enda voru téðir stuðlar lægri en peir sem reiknuðust milli TOLD-2P og mælieininga úr málsýnum. Ein möguleg ástæða pess er smæð úrtaksins sem hefur bein áhrif á afköst rannsóknarinnar sem eru minni fyrir vikið. Önnur ástæða gæti verið sú að prófið tekur á einum frekar afmörkuðum pætti. Til skýringar má benda á að prófpátturinn hlustun í TOLD-2P er byggður upp af premur undirprófum (myndir - orð̋ekking, túlkun setninga og hljódgreining) par sem undirprófið myndir orłpekking er byggt upp á nánast sama hátt og PPVT-4. Pannig getur hugsast að orðskilningur (pað sem PPVT-4 mælir) einn og sér meti ekki nema hluta af pví sem mælieiningar málsýna meta. Dá er nauðsynlegt að rifja upp að PPVT-4 er ekki með íslensk viðmið og hér var notast við bandarísk viðmið sem hugsanlega gæti haft áhrif. Með petta í huga er rétt að benda á að peir fylgnistuðlar sem komu milli mælinga úr málsýnum og PPVT-4 voru jákvæðir og meðalsterkir prátt fyrir að tölfræðilega marktekt hafi vantað. Dannig má álykta að PPVT-4 meti a. m. k. að einhverju leyti sömu pætti og mælieiningar málsýna. Einnig er vert að hafa í huga að málsýni eru fyrst og fremst mæling á tjáningu en ekki skilningi pó að mælieiningar úr málsýnum tengist prófpættinum hlustun á TOLD-2P sterkt í pessari rannsókn.

\section{Hlutfallslegur fjöldi villna og villuflokkun}

Athugun á málfræðivillum er nokkuð sem málsýni af sjálfsprottnu tali bjóða upp á umfram upplýsingar sem hægt er að fá með notkun staðlaðra málproskaprófa. Hlutfall málfræðivillna er ein af mælieiningum málsýna og fljótlegt og auðvelt er að gera slíka greiningu með notkun forritsins Málgreinir. Hér var ákveðið að kanna villur hjá pátttakendum og setja í samhengi við niðurstöður íslenskra rannsókna. Rannsóknir á málfræðivillum hjá íslenskum börnum sýna að 
pær eru hlutfallslega mjög fáar og peim fer jafnframt fækkandi með auknum aldri (Jóhanna T. Einarsdóttir og Álfhildur Dorsteinsdóttir, 2015). Einhverfu börnin sem tóku pátt í pessari rannsókn sýndu hærra hlutfall málfræðivillna heldur en jafnaldrar peirra. Hér verður gerð grein fyrir hlutfallslegum fjölda villna í málsýnum einhverfra barna í rannsókninni. Dví næst verður flokkun villna skoðuð og sett í samhengi við pær tegundir villna sem íslensk börn gera í sjálfsprottnu tali.

Hlutfallslegur fjöldi málfræðivillna hjá íslenskum jafnöldrum pátttakenda pessarar rannsóknar liggur á bilinu 2,0\% (4;5 ára) og niður í 1,6\% (6;0 ára) (Jóhanna T. Einarsdóttir og Álfhildur Porsteinsdóttir, 2015). Detta pykir almennt lágt hlutfall og athyglisvert pegar litið er til pess að íslenska er flókið beygingamál og möguleikarnir á villum eru fyrir vikið meiri en í öðrum tungumálum eins og til dæmis ensku. Í ljósi slakra niðurstaðna á stöðluðum prófum og mælieiningum úr málsýnum koma niðurstöður hlutfallslegs villufjölda einhverfu barnanna ekki á óvart. Einnig kemur ekki á óvart að bað skuli vera talsverð dreifing á hlutfallslegum fjölda $(2,5 \%-8,72 \%)$ (sjá samantekt í Töflu 3). Detta virðist við fyrstu sýn ekki vera mikið af villum en ef tekið er mið af pví hversu fáar villur íslensk börn á pessum aldri gera, kemur fram önnur mynd. Pátttakandi 9 er svo dæmi sé tekið 6;1;5 ára (elstur pátttakenda) og er með hæsta villuhlutfallið $(8,72 \%)$ og pað er rúmlega fimm sinnum hærra en meðal villuhlutfall jafnaldra. Баð er að sama skapi athyglisvert að elsta barn úrtaksins sé með hæsta hlutfall málfræðivillna af öllum pátttakendunum og undirstrikar enn og aftur hinn mikla breytileika sem sést í málproska einhverfra barna. Hlutfallslegur meðalfjöldi málfræðivillna barnanna í rannsókninni er 5,4\% og er pað 1,5 prósentustigi meira en 2;5 til 3;0 ára börn gera. Darna sést að einhverfu börnin í pessari rannsókn gera talsvert fleiri villur í sjálfsprottnu tali en börn sem eru tiltölulega nýfarin að mynda setningar sem eru lengri en 2,7 segðir að meðaltali. Detta varpar mögulega enn skýrara ljósi á vanda einhverfra barna pegar kemur að formgerð málsins par sem ljóst pykir að vandi peirra nær talsvert út fyrir erfiðleika í málnotkun og félagslegum samskiptum. Með ítarlegri greiningu á tegundum villna eða skorti á algengum málproskavörðum eins og alhæfingum í beygingu sagna má kanna fyrir hvern og einn hvaða páttur formgerðar máls er skertur. Að sama skapi er hægt að koma auga á styrkleika og nota pá sem stoðir í pjálfun og meðferð.

Í erlendum rannsóknum á málsýnum af sjálfsprottnu tali er hlutfallslegur fjöldi villna ekki algeng mælieining. Dær rannsóknir par sem villur hafa verið athugaðar eru gamlar og ekki er auðvelt að bera pær saman við rannsóknir sem hafa verið gerðar á íslenskumælandi börnum. Dað sem hefur verið athugað er meðal annars nám ákveðinna málfræðiatriða (Bartolucci o.fl., 1980; Howlin, 1984) og tíðarmörkun sagna (Tager-Flusberg, 1989). Niðurstöður eru á pá leið að einhverf börn læra sum málfræðiatriði hægar og gera meira af villum sem koma að tíðarmörkun sagna. Dað má ef til vill segja að slíkar niðurstöður rími við niðurstöður pessarar rannsóknar í afar grófum dráttum en eins og áður sagði er erfitt að bera saman slíkar rannsóknir á villum milli tungumála. Varnagli sleginn um úrtök í gömlum rannsóknum á einhverfum börnum á einnig við hér og gerir allan samanburð frekar vafasaman.

Hlutfallslegur fjöldi villna í sjálfsprottnu tali gefur ákveðna mynd af skertum málproska einhverfra barna. Drátt fyrir pað gefur villufjöldi einn og sér ekki mikið af viðbótarupplýsingum sem gagnast við uppbyggingu meðferðar eða inngrips hjá einhverfum börnum með málproskaröskun eða sértækan málvanda. Með nánari flokkun eða greiningu villna í málsýni er hægt að kafa dýpra ofan í vanda hvers einstaklings og setja greiningu í samhengi við pær upplýsingar sem hafa fengist með stöðluðum prófum og mælieiningum úr málsýnum af sjálfsprottnu tali. Jóhanna Thelma Einarsdóttir (2016) birti á ráđstefnu Menntavísindasviðs Háskóla Íslands (Menntakviku) niðurstöður úr rannsókn par sem villur í sjálfsprottnu tali barna úr Gagnabanka Jóhönnu Einarsdóttur um málsýni (GJEUM) (Jóhanna Thelma Einarsdóttir, 2014) voru flokkaðar. Dar kom í ljós að langflestar villurnar komu fram í sagnorðum. Dar á eftir komu nafnorð, pví næst fornöfn, lýsingarorð og fleiri pættir. Flokkun villna í pessari rannsókn sýndi mjög svipað mynstur par sem flestar villurnar voru í sagnorðum og svo sami fjöldi í nafnorðum og fornöfnum en lýsingarorð komu par á eftir. Á eftir villum sem tengdust lýsingarorðum komu villur vegna brottfalls orða úr setningum. 
Einnig voru villur 1 atviksorðum, töluorðum og forsetningum ásamt rangri orðaröð en pær voru afar fáar og pað var ekki hægt að sjá neitt mynstur eða reglu í peim villum annað en að pær voru til staðar. Alhæfingar voru ekki algengar í niðurstöðum villuflokkunar en sáust hjá pátttakendum 2 og 5. Alhæfingar málfræðireglna gefa til kynna að ákveðinn málproski hafi átt sér stað (fer líklega eftir eðli alhæfingarinnar). Dátttakendur 2 og 5 mældust með hæstu málproskatölurnar par sem peir voru við neðri mörk meðaltals jafnaldra og pað má segja að pess vegna komi ekki á óvart að einmitt pessir tveir pátttakendur sýni alhæfingar málfræðireglna. Niðurstöður pessarar rannsóknar má túlka pannig að einhverfu börnin í úrtakinu sýni svipað mynstur og börn með dæmigerðan proska pegar kemur að flokkun villna eftir orðflokkum. Slíkar upplýsingar gæu gagnast pegar verið er að ákveða áherslupunkta í pjálfun eða kennslu, til dæmis pegar kemur að orðaforða, setningafræði og málfræði hjá barni með skertan málproska.

Auk flokkunar villna eftir orðflokkum og öðrum páttum er hægt að skoða gerðir málfræðivillna af mun meiri dýpt. Dað var ekki gert í pessari rannsókn vegna pess að úrtak 10 barna býður ekki upp á mikla flóru villna til pess að greina. Til pess pyrfti mun fleiri málsýni og nokkur aldursbil að auki. Engu að síður er ekki úr vegi að ræða hvað hægt er að skoða nánar með pví að greina villur sem fást úr málsýnum. Sem dæmi væri hægt að greina villur með nákvæmari málfræðilegri skírskotun eins og til dæmis hlutfall villna í tíðbeygingu sagnorða af heildarvillum sem tengdust sagnorðum. Að sama skapi væri hægt að skoða alhæfingar veikrar tíðbeygingar sagna, nafnháttarstig (notkun nafnháttar sagna í stað persónubeygingar hjá börnum sem eru yngri en tveggja ára), fleirtölumyndun nafnorða, notkun fornafna, kynbeygingu lýsingarorða og mun fleiri pætti. Ávinningur slíkra nákvæmnisgreininga gefur ekki eingöngu skýrari mynd af málproskalegum vanda einhverfra barna heldur er líka möguleiki á samanburði við rannsóknir sem hafa verið gerðar á íslenskumælandi börnum. Rannsóknir á villum í tali íslenskra barna hafa meðal annars tæpt á sambandi orðaforða og beygingar- og setningarpátta (Elín D. Dórðardóttir o.fl., 2002), pátíðarbeygingu (Hrafnhildur Ragnarsdóttir, 1998), fleirtölumyndun pekktra nafnorða og bullorða (Indriði Gíslason o.fl., 1986), kyni nafnorða og fornafna, ákveðnum greini, sterkri pátíð, págufalli, polfalli og kynbeygingu lýsingarorða og háttum sagna (Elín P. Dórðardóttir og Weismer, 1998). Auk pess hafa verið gerðar rannsóknir á villum í tali barna par sem íslensk börn með dæmigerðan proska eru borin saman við börn með málproskaröskun (sjá Elínu Dórðardóttur, 2008; Ragnheiði Dagnýju Bjarnadóttur, 2014). Rannsóknir á málproska einhverfra barna í flóknum beygingarmálum eins og íslensku gætu verið mikilvægar par sem pær upplýsingar sem fást, til dæmis með villugreiningum úr málsýnum, eru annars eðlis en pær sem koma úr málum með einfaldari málfræði og beygingar. Flestar rannsóknir sem hafa verið gerðar á málbroska einhverfra barna eru á enskumælandi börnum og spennandi væri að sjá niðurstöður sambærilegra rannsókna úr fleiri tungumálum með flóknari málfræði og beygingar.

\section{Takmarkanir og styrkleikar rannsóknarinnar}

Framkvæmd rannsóknarinnar gekk almennt vel en pað tók rannsakanda talsverðan tíma að nálgast pátttakendur og finna einhverf börn sem féllu undir pátttökuviðmið rannsóknarinnar. Sumir foreldrar/forráðamenn voru ekki tilbúnir til pess að taka pátt. Rannsóknarskeiðið varð lengra en áætlað var vegna pessa en pað hefur í sjálfu sér ekki áhrif á niðurstöður. Hér verður fjallað um atriði sem mögulega hefði verið hægt að útfæra betur.

Í fyrsta lagi er nauðsynlegt að fjalla um hversu vel úrtakið endurspeglar pýði einhverfra barna. Hér parf að athuga að aldursbilið er pröngt og pær ályktanir og alhæfingar sem hafa verið dregnar í umræðum takmarkast að einhverju leyti við petta tiltekna aldursbil. Pá er vert að nefna að úrtakið er lítið og var valið af hentugleika en tilviljunarúrtak er forsenda allra ályktana yfir á pýði og hefði pað verið betra. Hvað pátttöku varðar má vera að peir foreldrar sem ákváðu að heimila pátttöku barna sinna búi peim öđruvísi lífsskilyrði en peir sem ákváđu að taka ekki pátt. Hér verður ekki ályktað um slíkt en pó er vert að hafa í huga að börnum sem búa við mismunandi aðstæður hvað varðar aðstandendur og heimili, farnast á mismunandi hátt. Kynjaskipting úrtaksins 
var skökk par sem níu pátttakendur voru drengir en aðeins ein stúlka tók pátt. Ef tekið er mið af tölum um algengi má álykta að stúlkur hefðu mátt vera fleiri í úrtakinu til pess að endurspegla pýðið betur. Möguleg ástæða pessarar skekkju er smæð úrtaksins.

Í öðru lagi parf að taka fram að ekki var farið nánar út í aðrar greiningar og hömlur sem pátttakendur gætu verið með. Rannsakandi hafði ekki aðgang að greindartölum svo dæmi sé tekið. Í rannsóknum sem pessum er gjarnan tekið tillit til áhrifsbreyta (t.d. greindartölu) með aðhvarfsgreiningum (e. regression analyses) til pess að aðgreina áhrif téðra breyta frá tengslum frum- og fylgibreyta í peim tilteknu dæmum. Slíkt var ekki gert hér og nauðsynlegt er að hafa pað í huga.

Í priðja lagi eru ákveðnir varnaglar sem parf að slá vegna notkunar staðlaðra prófa í pessari rannsókn. Hvað TOLD-2P varðar var reynt eftir bestu getu að fara eftir fyrirlagnarreglum í handbók prófsins. Vegna krefjandi hegðunar og strangra prófaðstæðna purfti í örfáum tilvikum að víkja frá fyrirlagnarreglum. Sem dæmi um pað má nefna notkun félagslegra styrkja (eins og hróss) á milli prófaðra atriða til pess að hvetja pátttakendur til pess að svara atriðum og halda áfram með hvert undirprófið á fæetur öðru. Endurgjöf er ekki heimil í fyrirlögninni og pað skal tekið fram að félagslegir styrkjar voru notaðir á pann hátt að verið var að styrkja svarhegðun almennt frekar en ákveðnar tegundir svara. Pannig voru styrkjar veittir almennt fyrir svörun og reynt að tengja pá ekki við ákveðin atriði. Detta purfti pó ekki að gera í mörgum tilfellum en vert er að nefna að petta gæti mögulega hafa haft smávægileg áhrif á niðurstöður. Annað atriði sem tengist TOLD-2P eru gólfhrif. Dau birtast í pví að stig fást fyrir frammistöđu sem sýnir ekki neina getu. Detta kom pó örsjaldan fyrir en par sem petta gerðist er möguleiki á að ofmat hafi átt sér stað. Hér parf að koma fram að orðaforðaprófið PPVT-4 hefur verið pýtt og staðfært en hefur ekki verið staðlað hérlendis. Pannig eru ekki til viðmið fyrir íslensk börn og pví er notast við erlend viðmið.

Rannsóknin er sú fyrsta hér á landi par sem skoðaðar eru mismunandi aðferðir við mat á málproska einhverfra barna. Málsýnataka og fyrirlögn prófa gekk snurðulaust fyrir sig og ekki vantaði gögn hjá neinum pátttakanda. Pá eru aðferðir sem notaðar eru í rannsókninni einfaldar, skýrar og aðgengilegar fyrir pá sem vilja gera rannsókn af svipuðu tagi, mögulega með stærra úrtak par sem tekið er tillit til aldurs og greindartölu pátttakenda. Niðurstöðurnar eru skýrar og nokkuð afgerandi sem gerir túlkun peirra frekar einfalda prátt fyrir að sérlega varlega skuli farið í pað sökum smæðar úrtaksins. Að lokum ætti rannsóknin að hvetja til notkunar málsýna samhliða stöðluðum prófum pegar verið er að meta málproska einhverfra barna.

\section{Ályktanir}

Gögnin sem koma fram í rannsókninni renna stoðum undir notagildi bæði staðlaðra prófa og málsýna af sjálfsprottnu tali pegar meta á málproska einhverfra barna. Sú sterka fylgni sem reiknaðist á milli mismunandi mælinga staðlaðra prófa og málsýna bendir til bess að hægt sé að fá nokkuð góða mynd af málproska með stöðluðum prófum í skipulögðum prófaðstæðum sem og málsýnum af sjálfsprottnu tali í óformlegri og náttúrulegri aðstæðum. Рað er bví ánægjulegt að sjá að prátt fyrir skerðingar sem tengjast félagslegum samskiptum, hegðun, máli og tali einhverfra barna, er mögulegt að meta málproska peirra með báðum tegundum fyrrgreindra matstækja. Frekari rannsókna á tengslum staðlaðra prófa og málsýna af sjálfsprottnu tali er pörf. Nauðsynlegt er að kanna fyrrgreind tengsl í stærra úrtaki með fleiri kvenkyns pátttakendum par sem úrtakið er valið af tilviljun frekar en hentugleik. Spennandi væri að kanna niðurstöður par sem tekið væri tillit til greindartölu, kyns, aldurs og jafnvel félags- og efnahagsstöðu foreldra pátttakenda. 


\section{Language assessment in children with autism: Relationship between standardized psychometric tests and language sample analysis}

Language assessment plays an important role in the diagnosis and treatment of children with autism spectrum disorders (ASD). Language impairment or deviation in language development is often one of the earliest symptoms that parents of the children are concerned about. Early language proficiency strongly correlates with long-term outcomes of academic and social functioning among children with ASD. Therefore, an early and accurate assessment of language skills in children with ASD is important. However, in many cases a valid assessment can be a complex task. A considerable portion of children with ASD respond poorly to standardized tests. Response failure may be the result of a lack of test taking skills or motivation in responding to specific test items. Many children with ASD have difficulty following the strict procedures that are required when using standardized tests. Language samples of spontaneous speech are often collected in addition to standardized tests with children with ASD. Language samples are usually elicited in conversation between an adult and the child in a natural environment. Language samples can, therefore, paint a picture of how the child is using language. The relationship between standardized measures of language and measures of spontaneous speech in children with ASD has not been examined in a grammatically complex language such as Icelandic. The relationship has mainly been investigated for English speaking children and in many studies participants have been typically developing children.

The main objective of this study was to compare different methods of language assessment for children with ASD. Language samples of spontaneous speech elicited in a natural environment were compared with the assessment of standardized language tests. A part of the objective was to assess what additional information can be derived from using language samples along with standardized tests. The second objective was to shed light on language acquisition in children with ASD when speaking Icelandic as well as to define the characteristics of speech, language, and the morphological and syntactic structure of language.

The criteria for participant inclusion were ASD (confirmed diagnosis by the Icelandic State Diagnostic and Counselling Centre), age (between 4 and 7 years) and language (enough knowledge of the Icelandic language to be able to take standardized language tests). Ten participants between the ages of 4;10 and 6;1 were selected by convenience. Two standardized tests (TOLD-2P and PPVT-4) were administered. In addition to the standardized tests, language samples were collected from all the participants. Bivariate Pearson's correlation was calculated for the results from the standardized tests and measures of spontaneous speech (mean length of utterance, total number of words, number of different words and the proportion of errors).

The results showed a moderately to very strong $(r=.67-.92)$, statistically significant correlation $(p<0,01$ and in more cases $p<0,001)$ between the results of TOLD-2P and measures of spontaneous speech. Correlations between PPVT- 4 and measures of spontaneous speech were moderately strong but lacked statistical significance. Analysis of grammatical errors in speech samples suggests that children with ASD make similar errors in spontaneous speech as their typically developing peers although a considerably higher percentage of errors was found in samples from the former group.

With a few caveats, this study concludes that standardized tests of language and measures of spontaneous speech tap the same underlying linguistic abilities in autistic children in a grammatically complex language such as Icelandic. Speech samples provide additional information when using them with standardized tests in language assessment of autistic children. Additional information appears in the form of a relative 
number of grammatical errors and the analysis of said errors. The importance of grammatical error analysis has not before been demonstrated in language assessment in autistic children. More research on language acquisition of Icelandic children with ASD is needed.

Key words: Language development, autistic spectrum disorder, standardized language tests, language samples

\section{Um höfunda}

Logi Pálsson M.Sc.logipals@gmail.com er talmeinafræðingur sem starfar á Talpjálfun Reykjavíkur og sérhæfir sig í talpjálfun barna með röskun á einhverfurófi og barna með flókinn fjölpættan vanda. Hann hefur starfað sem talmeinafræðingur frá 2018 og er með bakgrunn í sálfræði og atferlispjálfun.

Dr. Jóhanna Thelma Einarsdóttir (jeinars@hi.is) er prófessor við Háskóla Íslands, bæði á Menntavísindasviði og á Heilbrigðisvísindasviði. Hún hefur starfað sem talmeinafræðingur síðan 1987. Rannsóknir hennar hafa einkum beinst að mælingum og meðferð við stami sem og máltöku barna bæði hjá peim sem sýna eðlilega framvindu í máltökunni og peim sem sýna frávik.

\section{About the authors}

Logi Pálsson M.Sc. logipals@gmail.com is a speech and language pathologist practicing at Reykjavík Speech Center (Talbjálfun Reykjavíkur), specializing in intervention for children with autism spectrum disorders and children with complex multifaceted problems. He has been employed as a speech and language pathologist since 2018 and has a background in psychology and behavioral analysis.

Dr. Jóhanna Thelma Einarsdóttir (jeinars@hi.is) is a professor at the University of Iceland, School of Education and School of Health. She has been employed as a speech and language pathologist since 1987. Her research has focused on measures and treatment of fluency disorders as well as general language acquisition and measurement of developmental language disorders.

\section{Heimildir}

Bartolucci, G., Pierce, S. J. og Streiner, D. (1980). Cross-sectional studies of grammatical morphemes in autistic and mentally retarded children. Journal of Autism and Developmental Disorders, 10(1), 39-49. https:// doi.org/10.1007/bf02408431

Bishop, D. og Donlan, C. (2005). The role of syntax in encoding and recall of pictorial narratives: Evidence from specific language impairment. British Journal of Deveopmental Psychology, 23(1), 25-46. https://doi. org/10.1348/026151004x20685

Condouris, K., Meyer, E. og Tager-Flusberg, H. (2003). The relationship between standardized measures of language and measures of spontaneous speech in children with autism. American Journal of Speech-Language Pathology, 12(3), 349-358. https://doi.org/10.1044/1058-0360(2003/080)

Costanza-Smith, A. (2010). The clinical utility of language samples. Perspectives on Language Learning and Education, 17(1), 9-15. https://doi.org/10.1044/1le17.1.9

Drain, S. og Engelhardt, P. E. (2013). Naturalistic observations of nonverbal children with autism: A study of intentional communicative acts in the classroom. Child Development Research, 2013, 296039. https:// doi.org/10.1155/2013/296039 
Dunn, L. M. og Dunn, D. M. (2007). Peabody picture vocabulary test (4. útgáfa). Pearson.

Ebert, K. D. og Scott, C. M. (2014). Relationships between narrative language samples and norm referenced test scores in language assessments of school-age children. Language, Speech, and Hearing Services in Schools, 45(4), 337-350. https://doi.org/10.1044/2014_lshss-14-0034

Elín Dórðardóttir. (2008). Language-specific effects of task demands on the manifestation of specific language impairment: A comparison of English and Icelandic. Journal of Speech, Language, and Hearing Research, 51(4), 922-937. https://doi.org/10.1044/1092-4388(2008/068)

Elín P. Pórðardóttir og Weismer, S. E. (1998). Mean length of utterance and other language sample measures in early Icelandic. First Language, 18(52), 1-32. https://doi.org/10.1177/014272379801805201

Elín P. Dórðardóttir, Weismer, S. E. og Evans, J. (2002). Continuity in lexical and morphological development in Icelandic and English-speaking 2-year-olds. First Language, 22(1), 3-28. https://doi. org/10.1177/014272370202206401

Evald Sæmundsen, Páll Magnússon, Ingibjörg Georgsdóttir, Erlendur Egilsson og Vilhjálmur Rafnsson. (2013). Prevalence of autism spectrum disorders in an Icelandic birth cohort. BMJ Open, 3(6), 1-6. https://doi.org/10.1136/bmjopen-2013-002748

Finestack, L. H., Payesteh, B., Disher, J. R. og Julien, H. M. (2014). Reporting child language sampling procedures. Journal of Speech, Language, and Hearing Research, 57(6), 2274-2279. https://doi. org/10.1044/2014_JSLHR-L-14-0093

Hewitt, L. E., Hammer, C. S., Yont, K. M. og Tomblin, J. B. (2005). Language sampling for kindergarten children with and without SLI: Mean length of utterance, IPSYN, and NDW. Journal of Communication Disorders, 38(3), 197-213. https://doi.org/10.1016/j.jcomdis.2004.10.002

Howlin, P. (1984). The acquisition of grammatical morphemes in autistic children: A critique and replication of the findings of Bartolucci, Pierce and Streiner, 1980. Journal of Autism and Developmental Disorders, 14(2), 127-136. https://doi.org/10.1007/bf02409656

Hrafnhildur Ragnarsdóttir. (1998). Аð læra pátíð sagna. Í Baldur Sigurðsson, Sigurður Konráđsson og Örnólfur Thorsson (ritstjórar), Greinar af sama meiði: Helgaðar Indriða Gíslasyni sjötugum (bls. 255-276). Rannsóknarstofnun Kennaraháskóla Íslands.

Hrafnhildur Ragnarsdóttir. (2004). Málbroski barna við upphaf skólagöngu: Sögubygging og samloðun í frásögnum 165 fimm ára barna - almenn einkenni og einstaklingsmunur. Uppeldi og menntun, 13(2), 9-31.

Indriði Gíslason, Sigurður Konráđsson og Benedikt Jóhannesson. (1986). Framburður og myndun fleirtölu hjá 200 íslenskum börnum við fjögra og sex ára aldur. Kennaraháskóli Íslands.

Ingibjörg Símonardóttir, Einar Guðmundsson, Sigurgrímur Skúlason og Sigríður Pétursdóttir. (1995). TOLD2P: Málproskapróf, handbók, islensk staðfarsla. Rannsóknarstofnun uppeldis- og menntamála.

Jóhanna Thelma Einarsdóttir. (2014). Gagnabanki Jóhönnu Einarsdóttur um málsýni (GJEUM) [rafræn gögn]. http://malsyni.hi.is/

Jóhanna Thelma Einarsdóttir. (2016, 7. október). Málfraðivillur - hvað segja par okkur? [erindi flutt á Menntakviku, ráðstefnu Menntavísindasviðs Háskóla Íslands].

Jóhanna T. Einarsdóttir og Álfhildur Porsteinsdóttir. (2015). Málsýni leikskólabarna: Aldursbundin viðmið. Netla - veftímarit um uppeldi og menntun. https://ojs.hi.is/netla/article/view/2410/1296

Jóhanna Thelma Einarsdóttir og Stefán Carl Peiser. (2016). Málgreinir: Greining og úrvinnsla á málsýnum. http://malsyni.hi.is/

Jóhanna Thelma Einarsdóttir og Póra Sæunn Úlfsdóttir. (2016). Málsýnataka: Gagnabanki Jóhönnu T. Einarsdóttur um málsýni GJEUM: Handbók. http://malsyni.hi.is/

Kasari, C., Brady, N., Lord, C. og Tager-Flusberg, H. (2013). Assessing the minimally verbal school-aged child with autism spectrum disorder. Autism Research, 6(6), 479-493. https://doi.org/10.1002/aur.1334

Kover, S. T., Davidson, M. M., Sindberg, H. A. og Weismer, S. E. (2014). Use of the ADOS for assessing spontaneous expressive language in young children with ASD: A comparison of sampling contexts. Journal of Speech, Language, and Hearing Research, 57(6), 2221-2233. https://doi.org/10.1044/2014_jslhr-1-13-0330

Kover, S. T., McDuffie, A., Abbeduto, L. og Brown, W. T. (2012). Effects of sampling context on spontaneous expressive language in males with fragile X syndrome or Down syndrome. Journal of Speech, Language, and Hearing Research, 55(4), 1022-1038. https://doi.org/10.1044/1092-4388(2011/11-0075) 
Manning, B. L., Harpole, A., Harriott, E. M., Postolowicz, K. og Norton, E. S. (2020). Taking language samples home: Feasibility, reliability, and validity of child language samples conducted remotely with video chat versus in-person. Journal of Speech, Language, and Hearing Research, 63(12), 3982-3990. https:// doi.org/10.1044/2020_JSLHR-20-00202

Manolitsi, M. og Botting, N. (2011). Language abilities in children with autism and language impairment: Using narrative as an additional source of clinical information. Child Language Teaching and Therapy, 27(1), 39-55. https://doi.org/10.1177/0265659010369991

Mody, M. og Belliveau, J. W. (2013). Speech and language impairments in autism: Insights from behavior and neuroimaging. North American Journal of Medicine and Science, 5(3), 157-161. https://doi.org/10.7156/ v5i3p157

Muller, K. og Brady, N. (2016). Assessing early receptive language skills in children with ASD. Perspectives of the ASHA Special Interest Groups, 1(1), 12-19. https://doi.org/10.1044/persp1.sig1.12

Norbury, C. F. og Bishop, D. V. M. (2003). Narrative skills of children with communication impairments. International Journal of Language and Communication Disorders, 38(3), 287-313. https://doi. org/10.1080/136820310000108133

Nordahl-Hansen, A., Kaale, A. og Ulvund, S. E. (2014). Language assessment in children with autism spectrum disorder: Concurrent validity between report-based assessments and direct tests. Research in Autism Spectrum Disorders, 8(9), 1100-1106. https://doi.org/10.1016/j.rasd.2014.05.017

Paul, R. Norbury, C. og Gosse, C. (2018). Language disorders from infancy through adolescence: Listening, speaking, reading, writing, and communicating (5. útgáfa). Elsevier.

Phelps-Terasaki, D. og Phelps-Gunn, T. (1992). Test of pragmatic language (TOPL). Pearson.

Ragnheiður Dagný Bjarnadóttir. (2014). Málsýni sex ára barna: Samanburður á málsýnum sex ára barna með og án málproskaröskunar [meistararitgerð]. Skemman. http://hdl.handle.net/1946/19861

Restrepo, M. A. (1998). Identifiers of predominantly Spanish-speaking children with language impairment. Journal of Speech, Language, and Hearing Research, 41(6), 1398-1411. https://doi.org/10.1044/jslhr.4106.1398

Stockman, I. J. (1996). The promises and pitfalls of language sample analysis as an assessment tool for linguistic minority children. Language, Speech, and Hearing Services in Schools, 27(4), 355-366. https://doi. org/10.1044/0161-1461.2704.355

Tager-Flusberg, H. (1989). A psycholinguistic perspective on language development in the autistic child. Í G. Dawson (ritstjóri), Autism: Nature, diagnosis and treatment (bls. 92-115). Guilford.

Tager-Flusberg, H. (2000). The challenge of studying language development in children with autism. Í L. Menn og N. Bernstein Ratner (ritstjórar), Methods for studying language production (bls. 313-332). Erlbaum.

Tager-Flusberg, H. og Calkins, S. (1990). Does imitation facilitate the acquisition of grammar? Evidence from a study of autistic, Down's syndrome and normal children. Journal of Child Language, 17(3), 591-606. https://doi.org/10.1017/s0305000900010898

Tager-Flusberg, H., Paul, R. og Lord, C. (2005). Language and communication in autism. Í F. Volkmar, R. Paul, A. Klin og D. Cohen (ritstjórar), Handbook of autism and pervasive developmental disorders: Diagnosis, development, neurobiology, and behavior (3. útgáfa, bls. 335-364). Wiley.

Tek, S., Mesite, L., Fein, D. og Naigles, L. (2014). Longitudinal analyses of expressive language development reveal two distinct language profiles among young children with autism spectrum disorders. Journal of Autism and Developmental Disorders, 44(1), 75-89. https://doi.org/10.1007/s10803-013-1853-4

Ukrainetz, T. A. og Blomquist, C. (2002). The criterion validity of four vocabulary tests compared with a language sample. Child Language Teaching and Therapy, 18(1), 59-78. https://doi. org/10.1191/0265659002ct227oa

Volden, J., Smith, I. M., Szatmari, P., Bryson, S., Fombonne, E., Mirenda, P., Roberts, W., Vaillancourt, T., Waddel, C., Zwaigenbaum, L., Georgiades, S., Duku, E. og Thompson, A. (2011). Using the preschool language scale, fourth edition to characterize language in preschoolers with autism spectrum disorders. American Journal of Speech-Language Pathology, 20(3), 200-208. https://doi.org/10.1044/10580360(2011/10-0035)

Waterhouse, L. og Fein, D. (1982). Language skills in developmentally disabled children. Brain and Language, 15(2), 307-333. https://doi.org/10.1016/0093-934x(82)90062-1 
World Health Organization (WHO). (1993). The ICD-10 classification of mental and behavioral disorders: Diagnostic critera for research.

Zaidman-Zait, A., Mirenda, P., Szatmari, P., Duku, E., Smith, I. M., Zwaigenbaum, L., Vaillancourt, T., Kerns, C., Volden, J., Waddel, C., Bennett, T., Georgiades, S., Ungar, W. J. og Elsabbagh, M. (2021). Profiles and predictors of academic and social school functioning among children with autism spectrum disorder. Journal of Clinical Child \& Adolescent Psychology, 50(5), 656-668. https://doi.org/10.1080/153 74416.2020.1750021

Logi Pálsson og Jóhanna Thelma Einarsdóttir. (2021).

Mat á málproska barna sem greind eru með einhverfu: Tengsl staðlaðra prófa og málsýna Netla - Veftímarit um uppeldi og menntun. Menntavísindasvið Háskóla Íslands.

Sótt af http://netla.hi.is/greinar/2021/alm/15

DOI: https://doi.org/10.24270/netla.2021.15 